\title{
Geologia
}

\section{The Re-Os Isotopic System: Geochemistry and Methodology at the Geochronological Research Center (CPGeo) of the University of São Paulo, Brazil}

\author{
Ciro Teixeira Correia' (ccorrei@usp.br), Jason Donald Kirk', Louise Ruth Frick², \\ Liliane Aparecida Petronilho', Colombo Celso Gaeta Tassinari', Kei Sato' \\ 'Centro de Pesquisas Geocronológicas - Instituto de Geociências - USP \\ R. do Lago 562, CEP 05508-080, São Paulo, SP, BRA \\ ${ }^{2}$ EWL Science Pty Ltd., Winnellie, Northern Territory, AUS
}

Received 21 November 2006; accepted 06 March 2007

Keywords: Re-Os system, osmium, rhenium, isotope geochemistry, geochronology, analytical methodology.

\begin{abstract}
The Re-Os isotopic system is an important tool for the study of mantle-crust processes, geochronology and the tracing of source reservoirs for metal deposition. Rhenium and osmium differ fundamentally from other lithophile isotopic systems with regards to their behavior during partial melting processes, coupled with the chalcophile/siderophile nature of both elements. These differences make the system extremely useful for a number of novel applications not traditionally addressed by lithophile isotopic systems. A low-blank technique for the analysis of Re-Os isotopes in geological materials has been established at the Geochronological Research Center (CPGeo) of the Geosciences Institute of the University of São Paulo, Brazil, with the aim of furthering knowledge of regional geology, tectonic evolution, petrology and ore deposition in South America. The techniques described here use isotope dilution to simultaneously determine the concentration of Os and Re as well the Os isotopic composition of geologic materials. Sample digestion and sample-isotopic spike equilibration are achieved in sealed borosilicate glass tubes at high temperature. Osmium is separated and purified by carbon tetrachloride solvent extraction and micro-distillation techniques. Rhenium is separated and purified by anion exchange chromatography. Accuracy of the concentration and isotopic determinations is monitored by the analysis of a certified reference material (WPR-1) and the use of the Department of Terrestrial Magnetism (DTM) Os isotopic standard. Measured values and precision of these standards is within error and comparable to established Re-Os laboratories.
\end{abstract}

Palavras-chave: sistema Re-Os, ósmio, rênio, geoquímica isotópica, geocronologia, metodologia analítica.

\section{RESUMO}

O sistema isotópico Re-Os é um método importante para estudos relacionados com interações manto-crosta, geocronologia e os potenciais reservatórios responsáveis pela formação de depósitos de metais. Rênio e ósmio diferem sustancialmente dos demais sistemas isotópicos litófilos quanto ao comportamento durante os processos de fusão parcial e por conta das afinidades que apresentam com os elementos cobre e ferro. Essas diferenças tornam o sistema extremamente útil com relação a várias aplicações não convencionais e não cobertas pelos demais sistemas isotópicos litófilos. Uma técnica com baixos níveis de branco para análises de isótopos de Re-Os em materiais geológicos foi implantada no Centro de Pesquisas Geocronológicas (CPGeo) do Instituto de Geociências da Universidade de São Paulo, Brasil, com o propósito de avançar no conhecimento da geologia regional, evolução tectônica, petrologia e processos de formação de depósitos minerais na América do Sul. As técnicas ora descritas se utilizam de diluição isotópica para determinar simultaneamente as concentrações de Os e Re, assim como as composições isotópicas de Os de materiais geológicos. A digestão das amostras e a equilibração amostraspike isotópico se processam em tubos selados de borossilicato em altas temperaturas. Ósmio é separado e purificado via extração em solvente de tetracloreto de carbono e por técnicas de micro-destilação. Rênio é separado e purificado por cromatografia de troca iônica. A acurácia das concentrações e das determinações isotópicas é monitorada através de análises de um material de referência certificado (WPR-1) e pela utilização do padrão isotópico de Os fornecido pelo Department of Terrestrial Magnetism (DTM), de Washington. Os valores medidos e a precisão obtida para estes padrões se encontram nos intervalos de erros dos demais laboratórios Re-Os do mundo. 


\section{INTRODUCTION}

Within the last few decades, the Re-Os isotopic system has become one of the most sought after analytical methods available using existing laboratory and mass spectrometer facilities. The now routine measurement of the variation in isotopic composition of Os as a result of the decay of ${ }^{187} \mathrm{Re}$ has provided a large amount of geochronological and source tracing data on a variety of geologic material and processes. Rhenium and osmium are variably chalcophile, siderophile and organophile in behavior and as such preferentially partition into metal, sulfide and organic phases. These elements provide a very different record of geochemical processes than other traditionally used lithophile isotopic systems such as Rb-Sr, Sm-Nd, Lu-Hf, and $\mathrm{U}-\mathrm{Pb}$, which are found in significant concentrations only in silicate minerals. In contrast to the very incompatible behavior of both parent and daughter elements in all of these lithophile systems, Re and Os have widely disparate compatibilities and therefore yield complementary information, addressing important gaps in understanding the geochemistry and geochronology of mantle differentiation (Brandon et al., 2000; Pearson et al., 1995a, 1995b, 1999; Walker et al., 1989, 2002). The system has also been widely applied within the earth and planetary sciences to a number of diverse and novel applications including the study of variety of ore minerals and deposit types (Foster et al., 1996; Lambert et al., 1998; Kirk et al., 2001, 2002; Mathur et al., 2002; McCandless et al., 1993; Girardi et al., 2006), cosmochemistry (Walker et al., 1998, 2004; Brandon et al., 2000b), meteorites (Smoliar et al., 1996; Chen et al., 1998), and shales (Kendell et al., 2006; Selby and Creaser, 2005).

It is the aim of the Centro de Pesquisas Geocronológicas (CPGeo), located at the University of São Paulo, Brazil, to establish a world class Re-Os isotope facility for the application of Re-Os isotopes to geological problems, one of tens in the world, and the only such laboratory currently operating in South America.

\section{GEOCHEMISTRY AND ISOTOPIC SYSTEMATICS}

\section{Isotopic abundances}

Rhenium has two naturally occurring isotopes (Figure 1), ${ }^{185} \operatorname{Re}(37.4 \%)$ and ${ }^{187} \operatorname{Re}(62.6 \%)$, the former being stable whereas the later decays by $\beta$-emission to ${ }^{187}$ Os with a half life $\left(\mathrm{t}_{1 / 2}\right)$ of $\sim 42 \operatorname{Byr}\left(\lambda=1.666 \times 10^{-11} \mathrm{y}^{-1}\right.$ (Smoliar et al., 1996). Osmium has seven naturally occurring isotopes (Figure 1) with the atomic abundances varying to some degree as ${ }^{186}$ Os and ${ }^{187}$ Os are produced by the decay of ${ }^{190} \mathrm{Pt}\left(\mathrm{t}_{1 / 2}\right.$ of $\left.\sim 450 \mathrm{Byr}\right)$ and ${ }^{187} \mathrm{Re}$, respectively. Prior to the early 1990 's radiogenic ${ }^{187}$ Os was normalized to ${ }^{186} \mathrm{Os}$, and radiogenic isotopic compositions reported as ${ }^{187} \mathrm{Os} /{ }^{186} \mathrm{Os}$ ratios. However, as ${ }^{186} \mathrm{Os}$ is itself a product of radioactive decay, this normalization scheme was abandoned in favor of reporting ${ }^{187} \mathrm{Os} /{ }^{188} \mathrm{Os}$ ratios. Formerly reported ${ }^{187} \mathrm{Os} /{ }^{186} \mathrm{Os}$ ratios can be converted to ${ }^{187} \mathrm{Os} /{ }^{188} \mathrm{Os}$ ratios by multiplying by a factor of 0.1199 (from isotopic data reported in Shirey and Walker, 1998).

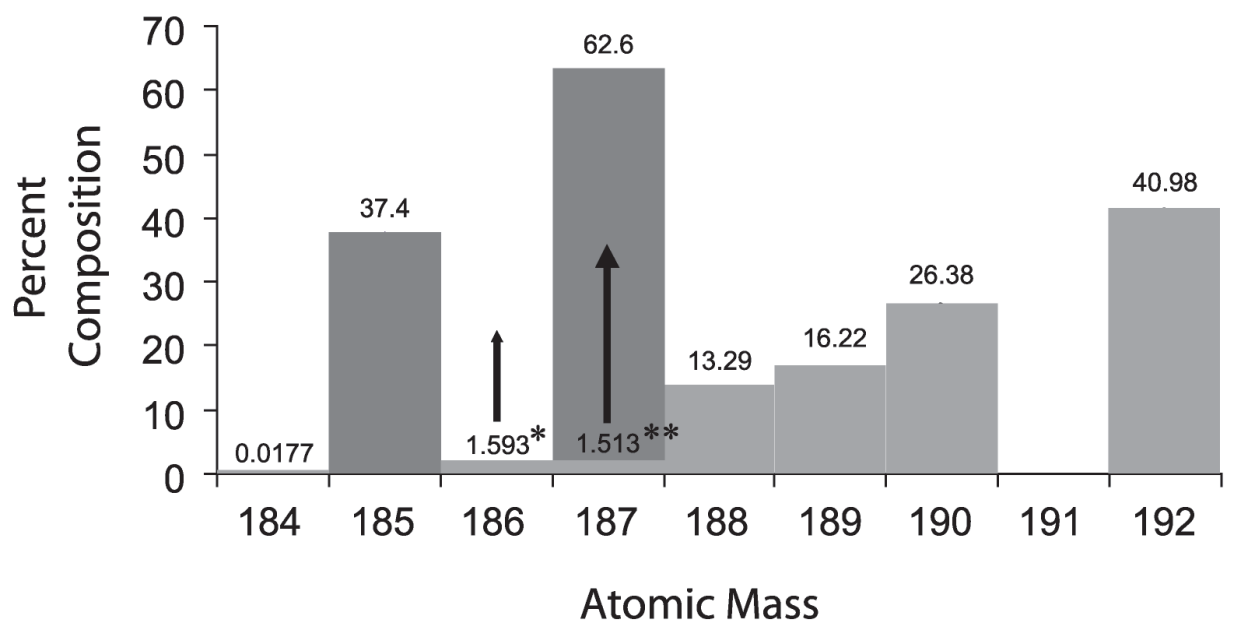

Figure 1. Rhenium (dark gray) and Osmium (light gray) isotopic percentages (Shirey and Walker, 1998). Isotopic percentages for Os are variable as masses 186 and 187 are variable depending on addition by radioactive decay of $\left({ }^{*}\right)^{190} \mathrm{Pt}\left(\lambda=1.54 \times 10^{-12} \mathrm{y}^{-1}\right)$ and $\left({ }^{* *}\right){ }^{187} \operatorname{Re}\left(\lambda=1.666 \times 10^{-11} \mathrm{y}^{-1}\right)$. 


\section{Geochemical behavior}

Osmium, one of the platinum group elements (PGE), as well as Re are classified as highly siderophile elements (HSE) and were almost exclusively concentrated in the core during planetary differentiation, with lesser abundances within the mantle and crust (Shirey and Walker, 1998). This siderophile behavior is reflected in their distribution coefficients between metal and silicates, which are greater than $10^{4}$ (e.g. Holzheid et al., 2000) and their chalcophile nature by distribution coefficients between sulfide and silicate melt with orders of magnitude from $10^{1}$ to $10^{3}$ for Re (Roy-Barman et al., 1998; Jones and Drake, 1986) and $3.0 \times 10^{4}$ to $4.8 \times 10^{4}$ for Os (Crocket et al., 1992; Roy-Barman et al., 1998). However, during mantle differentiation, even in the absence of residual sulfides (Carlson, 2005, and references therein) Os behaves as a compatible element, being retained in mantle residues such as depleted peridotites, whereas Re behaves relatively incompatibly, and is partially removed from the mantle source by the resulting melt. Crustal materials therefore generally are very depleted in Os and relatively enriched in Re (high $\mathrm{Re} / \mathrm{Os}$ ratios), whereas the convecting mantle has chondritic (specifically ordinary and enstatite chondrites) to subchondritic (sub-continental lithospheric mantle, SCLM) Re/Os ratios (Walker et al., 1989; Meisel et al., 1996). This large fractionation of parent and daughter during mantle melting and the subsequent radiogenic in-growth of ${ }^{187} \mathrm{Os}$ results in orders of magnitude variation in the ${ }^{187} \mathrm{Os} /{ }^{188} \mathrm{Os}$ ratios of geologic reservoirs (Figure 2), and also allows for the determination of ages in both extremely old and relatively young materials (a few million years), despite the long halflife of Re.

\section{Source tracing}

As with many other radiogenic isotopic systems, measured isotopic compositions are often compared to mantle reservoirs through geologic time. With systems such as $\mathrm{Rb}$-Sr or Sm-Nd the difference between the age-corrected measured ratio and the isotopic composition calculated for the mantle of the same age is expressed as parts per ten thousand. However, as stated earlier, the disparate geochemical behavior of $\mathrm{Re}$ and Os during mantle differentiation leads to orders of magnitude differences between mantle and crustal material, and this difference can therefore be expressed as parts per hundred, i.e. percent difference. Mantle and crustal reservoirs are distinctly different from each other as illustrated by the $\gamma$ Os values in Figure 3.

Gamma Os is determined by the following expression:

$$
\gamma_{\text {Os }}=\left\{\left[\left({ }^{187} \mathrm{Os} /{ }^{188} \mathrm{Os}_{\text {sample(t) }}\right) /\left({ }^{187} \mathrm{Os} /{ }^{188} \mathrm{Os}_{\text {mantle(t) }}\right)\right]-1\right\} \times 100
$$

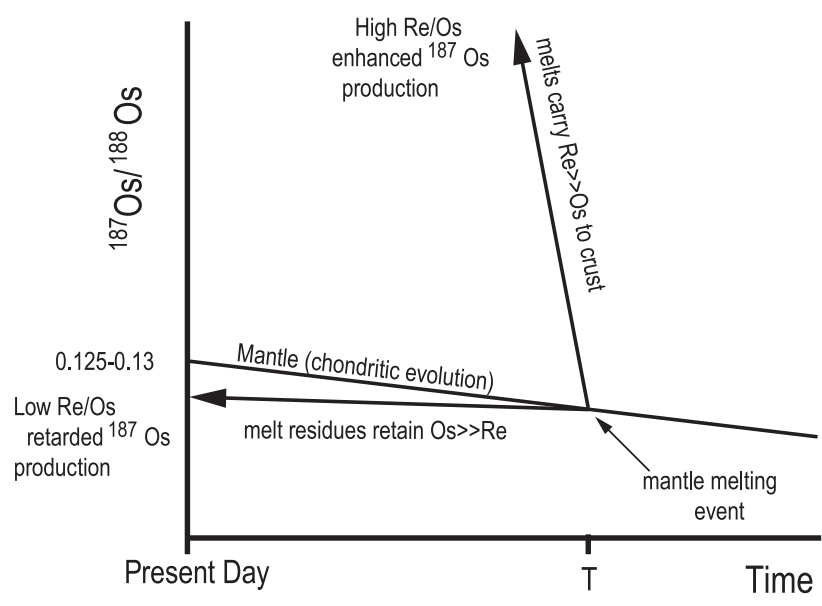

Figure 2. Schematic diagram of the evolution of crust and mantle components for a melting event at time T. The ${ }^{187} \mathrm{Os} /{ }^{188} \mathrm{Os}=0.1296$ (Meisel et al., 2001) is the present day isotopic composition of the fertile convecting upper mantle.

where $\left({ }^{187} \mathrm{Os} /{ }^{188} \mathrm{Os}_{\text {sample(t) }}\right)$ is the age corrected Os isotopic ratio of the sample and is compared to the ${ }^{187} \mathrm{Os} /{ }^{188} \mathrm{Os}$ of the mantle at the same age. The ${ }^{187} \mathrm{Os} /{ }^{188} \mathrm{Os}$ of the mantle for any particular age can be calculated using the following formula:

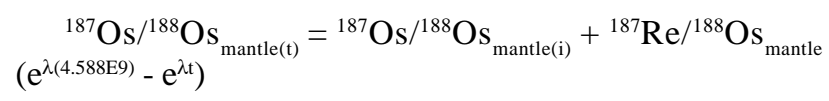

which defines the evolution of earth's mantle in terms of ReOs. However, much debate and uncertainty surrounds the selection of the mantle Re-Os values to be used for these models. We use the term mantle here, in order to include the various terminologies used in the literature such as bulksilicate earth (BSE), chondritic uniform reservoir (CHUR), chondritic reference, primitive upper mantle (PUM), fertile mantle and depleted MORB mantle (DMM). With the exception of the DMM, these terms describe the same reservoir in Re-Os space and refer to hypothetical fertile, convecting mantle with no previous melt extraction or enrichment. Essentially, in order to calculate $\gamma O$ s or Os model ages (see below) it is necessary to determine the slope of the line that defines the growth of ${ }^{187}$ Os in the mantle as a result of Re decay. Therefore two of the following three parameters must be known:

1. the initial (i) ${ }^{187} \mathrm{Os} /{ }^{188} \mathrm{Os}$ of the mantle $\left({ }^{187} \mathrm{Os} /{ }^{188} \mathrm{Os}_{\text {mantle(i) }}\right)$;

2. the ${ }^{187} \mathrm{Os} /{ }^{188} \mathrm{Os}$ of the mantle today $\left({ }^{187} \mathrm{Os} /{ }^{188} \mathrm{Os}_{\text {mantle }(\mathrm{t}=0)}\right)$;

3. the ${ }^{187} \mathrm{Re} /{ }^{188} \mathrm{Os}$ of the mantle. 


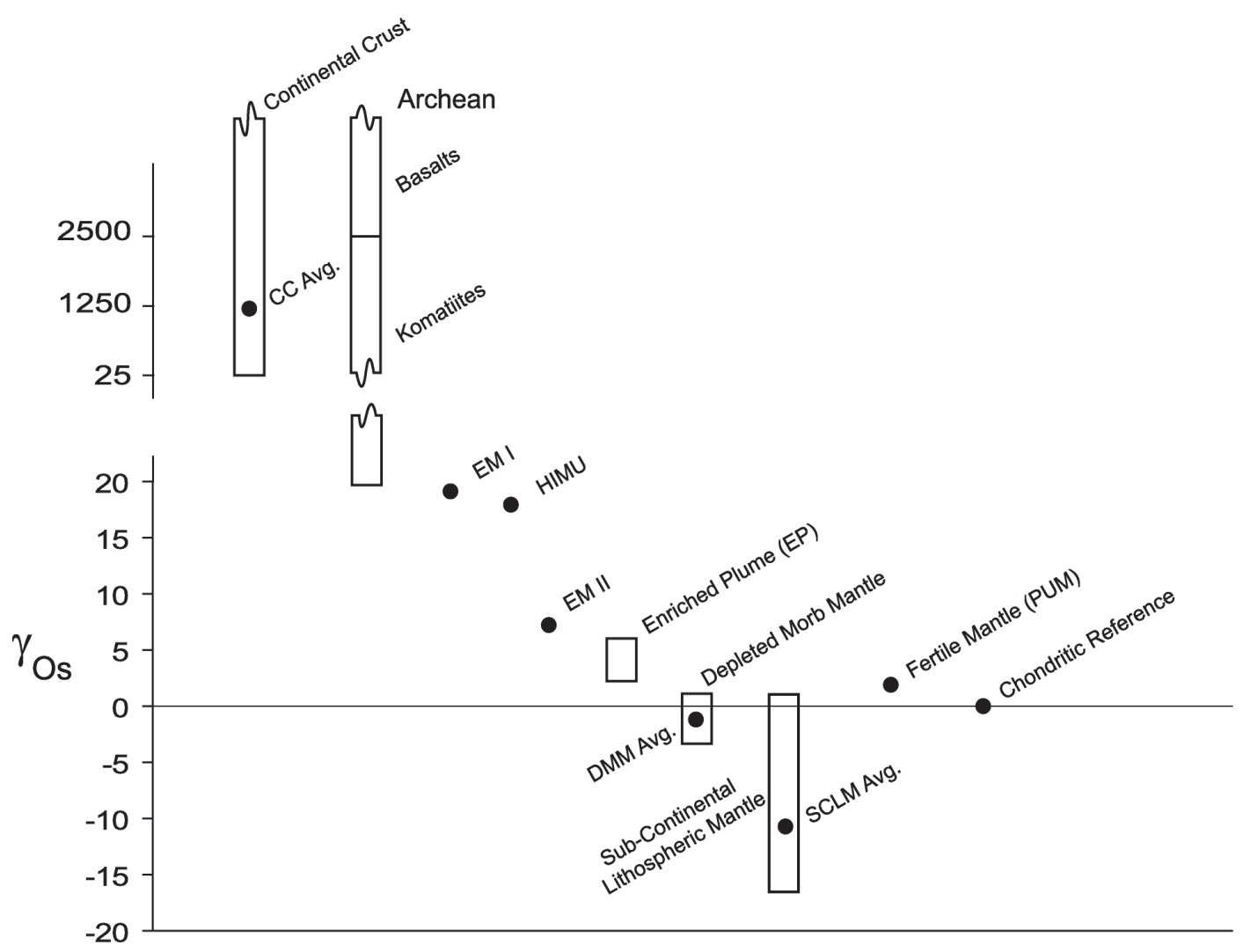

Figure 3. Gamma Os compositions of various rock types. Note that values are from sources (Shirey and Walker, 1998; Pearson et al., 1999, and sources therein) that calculated gamma Os for these reservoirs using a ${ }^{187} \mathrm{Os} /{ }^{188} \mathrm{Os}$ value for the present day mantle of 0.127 , and not necessarily the age of crystallization, and thus illustrate possible sources of present day magmatism.

The ${ }^{187} \mathrm{Os} /{ }^{188} \mathrm{Os}$ mantle(i) has been determined through analyses of various suites of iron meteorites with values at 4.56 Ga ranging from 0.09524 to 0.09604 (Chen et al., 1998 and references therein); however, a value of 0.09531 determined from initial values of IIIA iron meteorites (Shirey and Walker, 1998) seems to be in most common use. Iron meteorites are used to determine the initial Os isotopic composition of the mantle as they are thought to have crystallized early in the formation of the solar system (Smoliar et al., 1996) and as such represent a uniform reservoir of initial Os also sampled by chondritic material, and unlike chondritic meteorites display isochronous behavior (Walker et al., 2002).

Estimates for ${ }^{187} \mathrm{Os} /{ }^{188} \mathrm{Os}$ mante(t=0) have variously been determined through measurement of present day ${ }^{187} \mathrm{Os} /{ }^{188} \mathrm{Os}$ ratios in chondritic meteorites with values of 0.1262-0.1286 (Walker and Morgan, 1989; Chen et al., 1998; Walker et al., 2002), as well as mantle xenoliths and orogenic lherzolite suites that have been corrected for melt depletion and yield a value of 0.1296 (PUM of Meisel et al., 2001). The values of 0.127 (Walker and Morgan, 1989) and 0.1296 (Meisel el al., 2001) are the most commonly cited. Estimates for the DMM were determined from various sources and include chromites and whole rock data from ophiolites (Luck and Allègre, 1991; Walker et al., 2002), as well as abyssal peridotites (Snow and Reisberg, 1995; Brandon et al., 2000), with values ranging from 0.120 to 0.129 . The value from Snow and Reisberg (1995), of 0.1247 has been the most often cited for the DMM but there are large variations in the measured Os isotopic compositions of abyssal peridotites which may indicate inhomogeneous source regions or problems with seafloor alteration (Walker et al., 2002), and therefore the more recent value (0.1281) of more resistant chromites reported by Walker et al. (2002) may be more representative.

Using the above data, the ${ }^{187} \mathrm{Re} /{ }^{188} \mathrm{Os}$ ratio of the mantle can be calculated resulting in the most commonly used values of 0.40186 (Shirey and Walker, 1998) and 0.4353 (Meisel et al., 2001). These values are also very similar to direct measure- 
ments on ordinary and enstatite chondrites with values of 0.42 - 0.47 (Chen et al., 1998; Walker et al., 2002).

In addition to fertile mantle and DMM, other enrichedmantle sources in terms of Os isotopic composition are also present. One possible explanation for the differences between the Os isotopic compositions of these enriched mantle sources and of the present day values for PUM and DMM is the formation and long-term isolation of the subducted oceanic crust (Walker et al., 2002). In addition to other possible scenarios, melting of these isolated slabs enriched in ${ }^{187}$ Os may produce distinctive isotopic signatures similar to those found in HIMU and EM basalts (Figure 3).

\section{Geochronology}

\section{Model ages}

As with other isotopic systems, and with the above data on the Os isotopic evolution of the mantle reservoir, model ages can be calculated with the following equation:

$$
\begin{aligned}
& \mathrm{T}_{\mathrm{MA}}=(1 / \lambda) * \ln \left\{\left[\left({ }^{187} \mathrm{Os} /{ }^{188} \mathrm{Os}_{\text {mantle(t=0) }}{ }^{-187} \mathrm{Os} /{ }^{188} \mathrm{Os}_{\text {sample }(\mathrm{t}=0)}\right) /\right.\right. \\
& \left.\left.\left({ }^{187} \mathrm{Re}^{/ 188} \mathrm{Os}_{\text {mantle(t=0)}}-{ }^{187} \mathrm{Re} /{ }^{188} \mathrm{Os}_{\text {sample }(t=0)}\right)\right]+1\right\}
\end{aligned}
$$

wherein the sample's measured ${ }^{187} \mathrm{Re} /{ }^{188} \mathrm{Os}$ ratio is used to regress the measured ${ }^{187} \mathrm{Os} /{ }^{188} \mathrm{Os}$ ratio to its intersection with the chondritic mantle growth curve and therefore determines the time of deviation from the Os isotopic composition of a mantle source reservoir (Figure 4).

The Re-Os model age $\left(\mathrm{T}_{\mathrm{MA}}\right)$ is analogous to depleted mantle model ages $\left(\mathrm{T}_{\mathrm{DM}}\right)$ of the $\mathrm{Rb}-\mathrm{Sr}$ and $\mathrm{Sm}-\mathrm{Nd}$ systems where the measured isotopic ratio is back-corrected to the isotopic composition of a mantle source reservoir using the measured parent-daughter ratio. However, the extremely low concentrations of $\mathrm{Rb}, \mathrm{Sr}, \mathrm{Sm}$ and $\mathrm{Nd}$ in mantle residual material as well as in mafic/ultramafic rocks limit the applicability of these systems to silicic rocks and make them susceptible to isotopic resetting via the high concentration of these elements in metasomatic fluids and melts (e.g. Chesley et al., 2004). In contrast, because of the relatively high Os concentration in mantle materials and mafic/ultramafic rocks, as well as the low Os concentrations in metasomatic fluids and melts, the Re-Os system is useful for mantle geochronology and is much more resistant to later resetting. Additionally, $\mathrm{T}_{\mathrm{MA}}$ ages can be can be a useful geochronologic tool for crustal materials and other phases with high $\mathrm{Re} /$ Os ratios.

Walker et al. (1989) observed that depleted lithospheric mantle peridotites have un-radiogenic isotopic compositions compared with the chondritic mantle and noted that many of these peridotite xenoliths had elevated Re/Os ratios despite the low, sub-chondritic Os isotopic ratios. These authors concluded that the measured Re/Os ratios were artificially elevated by contamination with the host rock during eruption and emplacement. This led to the concept of $\mathrm{T}_{\mathrm{RD}}$ ages, which are calculated using the following formula:

$$
\begin{aligned}
& \mathrm{T}_{\mathrm{RD}}=(1 / \lambda) * \ln \left\{\left[\left({ }^{187} \mathrm{Os} /{ }^{188} \mathrm{Os}_{\text {mantle }(\mathrm{t}=0)}-{ }^{187} \mathrm{Os} /\right.\right.\right. \\
& \left.\left.\left.{ }^{188} \mathrm{Os}_{\text {sample }(\mathrm{t}=0)}\right) /{ }^{187} \mathrm{Re} /{ }^{188} \mathrm{Os}_{\text {mantle(t=0)}}\right]+1\right\}
\end{aligned}
$$

which is the same as the formula for $\mathrm{T}_{\mathrm{MA}}$ ages, but assumes a post-crystallization origin for all of the Re (i.e. ${ }^{187} \mathrm{Re} /{ }^{188} \mathrm{Os}$ sample is assumed to be 0 ) and represents a minimum age of isolation from the convecting mantle (Figure 4). The $\mathrm{T}_{\mathrm{RD}}$ ages therefore assume that all of the Re in peridotite xenoliths was removed during the melt depletion events that formed the SCLM and likely approach actual ages of melt depletion for highly depleted peridotite xenoliths that experienced near complete Re removal.

These model age methods are especially applicable to materials such as peridotite xenoliths, osmiridium, and chromite, all of which have very low $\mathrm{Re} / \mathrm{Os}$ ratios resulting from either the lack of incorporation of structural Re or removal of Re during partial melting processes.

\section{Isochron ages}

The most useful geochronologic method is the classic isochron technique, using either whole rock or mineral separates, whereby material with varying Re/Os ratios evolve different Os compositions over time and that can then be used to graphically solve for both the age of the sample (based on the slope of the line) as well as the initial Os (Os $)$ isotopic composition (y-intercept), with the following formula:

$$
{ }^{187} \mathrm{Os} /{ }^{188} \mathrm{Os}_{\text {measured }}={ }^{187} \mathrm{Os} /{ }^{188} \mathrm{Os}_{\mathrm{i}}+{ }^{187} \mathrm{Re} /{ }^{188} \mathrm{Os}\left(\mathrm{e}^{\lambda \mathrm{t}}-1\right)
$$

With respect to igneous rocks, the ideal situation for obtaining a Re-Os isochron is in a closed, fractionating magma chamber, with whole rock samples collected that reflect different stages of the fractionating magmatic system. The whole rock samples may then provide a spread in Re/Os ratios not often obtained on single whole rock samples. The spread in Re/Os ratios will be controlled jointly by sulfide processes and the partitioning of Re into phases such as magnetite (Righter et al., 1998), and may yield statistically significant isochrons. Relatively few isochrons have been published for terrestrial rocks, probably as a result of low abundances of Os in igneous melts. Komatiites, picrites and flood basalts are notable exceptions due to their elevated PGE contents that result largely from high degrees of partial melting. In some cases sufficient spread of Re/Os ratios present in a single whole rock or mineral sample produces isochrons. This is a product of the notorious 


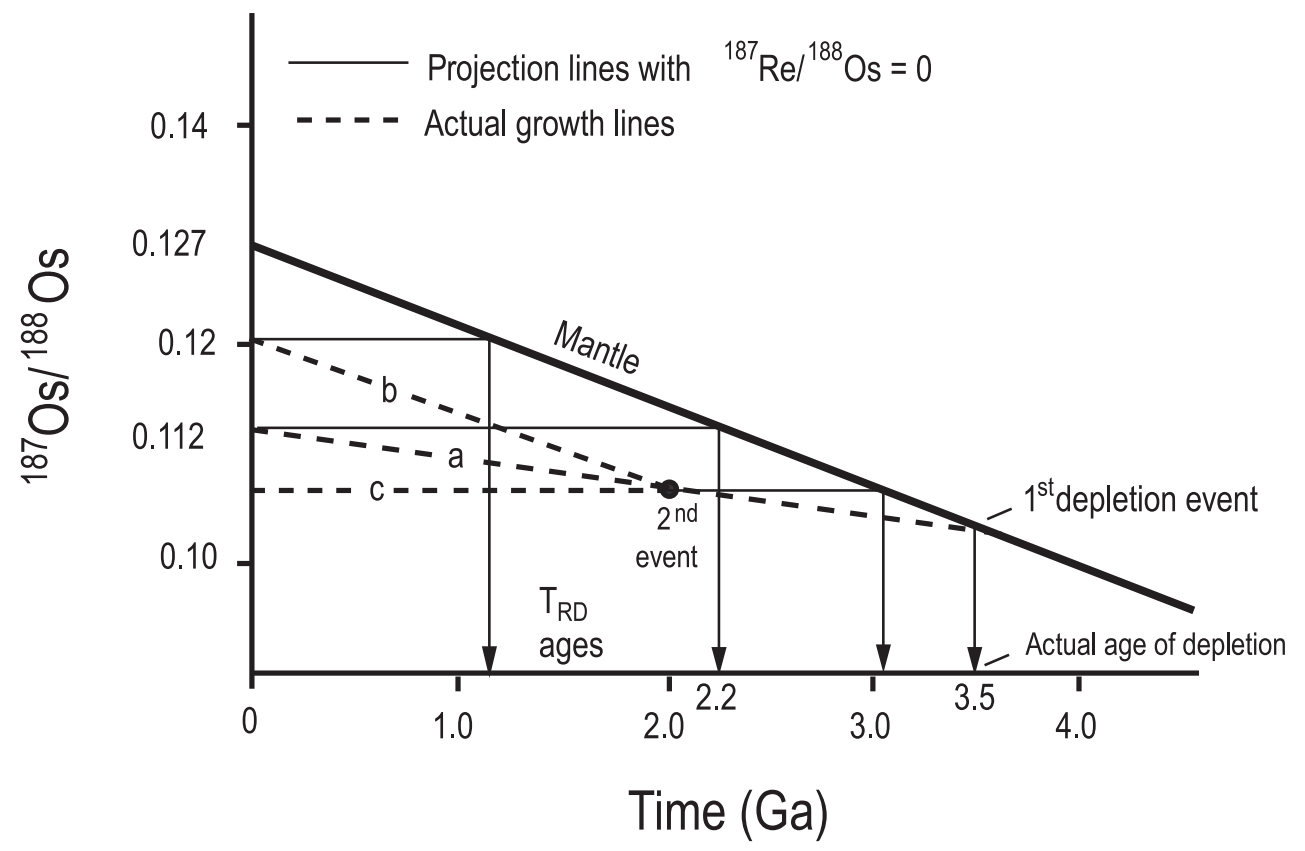

Figure 4. Illustration of the Re depletion model ages, with mantle composition modeled after Shirey and Walker, 1998. A mantle xenolith is depleted by melt extraction at $3.5 \mathrm{Ga}$, and evolves along path (a) with a ${ }^{187} \mathrm{Re} /{ }^{188} \mathrm{Os}$ of 0.15 (less than the chondritic mantle values of $\sim 0.4$ ) to the present day ${ }^{187} \mathrm{Os} /{ }^{188} \mathrm{Os}=0.112$. The $\mathrm{T}_{M A}$ for this sample is $\sim 3.5 \mathrm{Ga}$, while the $\mathrm{T}_{\mathrm{RD}}$ age is $2.2 \mathrm{Ga}$. Enrichment after the original depletion event along path (b) will only make the $\mathrm{T}_{\mathrm{RD}}$ age appear younger, while further complete depletion (i.e. the $30 \%$ melt extraction of Shirey and Walker, 1989) along path (c) will make the apparent age closer to the true depletion age. Even the addition of radiogenic Os by fluids or melts, as has been proposed to have occurred in some arc peridotites (Brandon et al., 1996; Mclnnes et al., 1998), will not compromise the validity of the $T_{R D}$ as a minimum model age. This demonstrates the robust nature of the $T_{R D}$ as a minimum age for Re depleted rocks. The high concentration of $O s$ in these rocks with respect to metasomatic fluids and melts also makes the $T_{R D}$ age uniquely resistant to later resetting and overprinting as often occurs with the $\mathrm{Rb}-\mathrm{Sr}$ and $\mathrm{Sm}-\mathrm{Nd}$ systems.

“nugget effect” (see Potts, 1987), wherein even finely powdered material has a large range in Re and Os concentrations and isotopic ratios and results from high concentration Re- and Os-bearing phases likely being heterogeneously distributed throughout a sample powder (e.g. Allègre and Luck, 1980).

In addition to igneous whole rocks, many black shales, sulfides (pyrite, chalcopyrite), oxides (magnetite) and gold also may have sufficient spread in Re/Os ratios and closedsystem behavior to form isochrons.

\section{Molybdenite ages}

Another useful geochronologic method is almost exclusively applied to molybdenite $\left(\mathrm{MoS}_{2}\right)$ and results from the virtual absence of common Os (not derived from ${ }^{187} \mathrm{Re}$ decay) in the mineral's structure. Rhenium on the other hand has an ionic radius comparable to Mo and the same valence state and therefore substitutes readily into the structure of molybdenite with concentrations in the ppb (parts per billion) to low percentage range (Luck and Allègre, 1982; McCandless et al., 1993). Ages are therefore obtained by using only the measured ${ }^{187} \mathrm{Re}$ and ${ }^{187} \mathrm{Os}$ abundances in the following simplified decay equation:

$$
\mathrm{T}=\left\{\ln \left[\left({ }^{187} \mathrm{Os} /{ }^{187} \mathrm{Re}\right)+1\right]\right\} / \lambda
$$

However, because time is the only unknown variable, no source information can be obtained for molybdenite with the Re-Os system. The Re-Os systematics measured in molybdenite have been successfully used for dating a number of economic ore deposits such as porphyry copper, base metal, and gold deposits (Mathur et al., 2002; Selby et al., 2002; Barra et al., 2005). Care must be exercised in sample selection however, as post-mineralization alteration as well as sometimes ambiguous paragenetic relationships with ore minerals complicates age interpretations (e.g. Luck and Allègre, 1982; McCandless et al., 1993). 


\section{ESTABLISHMENT OF THE Re-Os METHOD AT CPGeo}

\section{Production and calibration of Re and Os spikes}

The accuracy of Re-Os isotopic data is critically dependent on the accurate determination of the Re and Os concentration in the spikes. This in turn is contingent on the use of primary Re and Os chemical standards of accurately known concentration.

The primary standard for Re was made using Re metal, purchased from the Johnson Matthey Co. as a fine powder. The Re powder was dried in an oven at $70^{\circ} \mathrm{C}$ and weighed periodically until a constant weight was reached. Two standards of well-determined concentration were subsequently produced by dissolving the Re powder in $2 \mathrm{~N} \mathrm{HNO}_{3}$, producing a concentrated standard with a Re concentration of 232.9 ppm (parts per million) and then subsequently diluting with water to produce a more dilute standard of $113.5 \mathrm{ppb}$.

Producing an Os standard of accurate, precisely known concentration is more challenging. The standard is most commonly made from one of the Os salts, such as ammonium hexachlorosmate $\left(\left(\mathrm{NH}_{4}\right)_{2} \mathrm{OsCl}_{6}\right)$, which is dried to constant weight, weighed and then dissolved. These salts, while being the most readily available and commonly used for standard preparation, may not be completely stoichiometric (e.g. Yin et al., 2001), retain some water in the structure and may lead to relatively large uncertainties in the concentration of the standard (e.g. up to 1.6\%, Shen et al., 1996).

At CPGeo, the primary Os standard was prepared using ammonium hexachlorosmate. The salt was dried in an oven at $90^{\circ} \mathrm{C}$ for several days to minimize non-stoichiometric behavior. During this time, the mass of the vessel was periodically checked after returning the vessel to room temperature. Once the standard had reached constant weight, it was used to make two primary standards in $6 \mathrm{~N}$ hydrochloric acid, a concentrated standard of 44.40 ppm, and a dilute standard of 86.59 ppb Os.

The Os and Re isotopic spikes were obtained from the Oak Ridge National Laboratories in powdered metal form. A ${ }^{190}$ Os enriched solution was obtained by dissolving $5 \mathrm{mg}$ of metal powder in aqua regia within a Carius tube (borosilicate glass) at $100^{\circ} \mathrm{C}$. The solution was diluted into $6 \mathrm{~N}$ hydrochloric acid to make a stock solution of approximately $90 \mathrm{ppm}$. Two spikes were prepared from this stock solution, a concentrated spike with a concentration of approximately $67 \mathrm{ppb}$ and a dilute spike with a concentration of approximately $0.9 \mathrm{ppb}$. The ${ }^{185}$ Re enriched metal powder was initially digested in aqua regia, and diluted to make a stock solution of approximately 103 ppm. This stock solution was further diluted to make two lower concentration spike solutions for routine use of approximately of $32 \mathrm{ppb}$ and $3.5 \mathrm{ppb}$ Re.

The concentration of Re and Os spikes were calibrated by weighing and transferring appropriate amounts of spike and standard into PTFE vessels or Carius tubes, respectively. The amounts of each solution were chosen to provide as close to the optimum spike/sample ratio, using the estimated concentration of the Os and Re spikes. To ensure complete spike-standard equilibration the Re mixtures were heated at low temperature $\left(60^{\circ} \mathrm{C}\right)$ overnight while Os mixtures were heated in the sealed Carius tubes at $\sim 240^{\circ} \mathrm{C}$ (see below). The isotopic ratios of the Re and Os standard/spike mixtures were measured by N-TIMS analysis with corrections made for fractionation as well as the isotopic compositions of oxygen and the primary standards. A summary of the calibration data for the Os and Re spikes is presented in Table 1.

\section{Sample preparation methods}

Re-Os isotope geochemistry requires the precise determination of both the Os isotopic composition and the concentrations of Re and Os. This is accomplished by isotope dilution analysis of both Re and Os. The sample digestion, spike/sample equilibration and separation procedures are complicated by the geochemistry (refractory and under oxidizing conditions, extremely volatile) and very low concentrations of Os in terrestrial rocks: low ppt (parts per trillion) to $\mathrm{ppb}$.

The problem of ensuring spike/sample equilibration while also preventing spike loss has led to the rediscovery of an old technique of sample digestion under oxidizing conditions in sealed Carius tubes (borosilicate glass) (Walker and Fassett, 1986; Shirey and Walker, 1994; 1995). By this method, digestion and spike/sample equilibration is achieved under extremely oxidizing conditions while loss of the volatile Os is prevented.

Table 1. Results for the calibration of Os and Re spikes. ${ }^{*}=$ Concentrations in ppb, errors are $2 \sigma$.

\begin{tabular}{cccc}
\hline Dilute Os spike* $^{*}$ & Conc. Os spike & Dilute Re spike & Conc. Re spike \\
\hline $0.86910 \pm 0.00334$ & $66.651 \pm 0.206$ & $3.5798 \pm 0.0045$ & $31.950 \pm 0.003$ \\
$(n=6)$ & $(n=6)$ & $(n=9)$ & $(n=6)$ \\
\hline
\end{tabular}


In detail, the technique involves the digestion of a small amount of sample $(\leq 4 \mathrm{~g})$ in a $50 \mathrm{~mL}$ or $100 \mathrm{~mL}$ volume sealed borosilicate glass tube in reversed aqua regia (2:1, $\mathrm{HNO}_{3}: \mathrm{HCl}$ ), in the presence of Re and Os spikes. The reagents are frozen before the tube is sealed to inhibit reaction, which may oxidize the sample or spike Os to volatile $\mathrm{OsO}_{4}$. The narrow neck of the Carius tube is sealed using an oxygen-butane torch, and is then heated inside a steel bomb to contain possible explosive failures. The bomb is then either placed in an oven at $240^{\circ} \mathrm{C}$ overnight or for up to 5 days, depending on the ease of sample dissolution. Once cool, the tube is removed, frozen in liquid nitrogen, which condenses the volatile $\mathrm{OsO}_{4}$, and then opened.

\section{Separation and purification of $\mathrm{Os}$ and $\mathrm{Re}$}

The isobaric overlap of ${ }^{187} \mathrm{Re}$ and ${ }^{187}$ Os requires near complete chemical separation of sample Re and Os for mass spectrometric analysis. Cohen and Waters (1996) documented a technique that combines the Carius tube equilibration with the subsequent extraction of the equilibrated $\mathrm{Os}$ by the organic-solvents $\mathrm{CHCl}_{3}$ or $\mathrm{CCl}_{4}$. This method has been widely adopted within the Re-Os geochemistry community, and a similar method was utilized at CPGeo. The solvent extraction technique provides high extractive yield coupled with low procedural blanks and rapid throughput compared with distillation techniques. Once the Carius tube is opened after the high temperature equilibration, $4 \mathrm{~mL}$ of $\mathrm{CCl}_{4}$ solvent is added on top of the acid solution while still frozen. Once thawed, the aqua regia-solvent mixture is transferred to $50 \mathrm{~mL}$ falcon tubes, agitated and centrifuged to aid the extraction and separation of Os into organic-solvent and acidic layers. The organicsolvent layer containing the Os is separated from the acidic layer and the procedure is repeated twice more with $3 \mathrm{~mL}$ of $\mathrm{CCl}_{4}$ to ensure high Os yield. The Os is then back-extracted from the organic-solvent into concentrated hydrobromic acid, which is dried and subsequently purified for mass spectrometry by microdistillation techniques (Birk, 1997). The aqueous acidic layer, which contains the Re, is retained for separation and purification by $1 \mathrm{~mL}$ and $0.1 \mathrm{~mL}$ ionexchange column chemistry (Morgan and Walker, 1989), using the strong anion exchange resin AG-1 X8 stored in $\mathrm{MQH}_{2} \mathrm{O}$.

\section{Mass spectrometric analysis}

Re-Os mass spectrometry at CPGeo is performed on a Finnigan MAT 262 N-TIMS. Purified Re and Os fractions are run on single platinum filaments (99.995\% pure), which are loaded with barium nitrate and barium hydroxide, respectively, as emission enhancing agents. The filaments are heated slowly to a running temperature of approximately $800^{\circ} \mathrm{C}$ as measured by an optical pyrometer. Oxygen is introduced into the ion source through a variable leak valve, at a pressure of $1-2 \times 10^{-6}$ mbar for Os and 8-9 x 10-7 for Re. Earlier Os analyses loaded with barium nitrate ran at much higher temperatures than standards due to the presence of impurities in the loaded sample that inhibit the emission of ions. For this reason barium hydroxide is now used which eliminates the need for higher run temperatures or time consuming reduction of Os under high vacuum before the addition of barium nitrate. Osmium is collected as the negative $\mathrm{OsO}_{3}{ }^{-}$ion, which for low concentration samples is measured by a single ETP-type secondary electron multiplier with pulse counter in peak jumping mode with an integration time of 16 seconds and downtime of 8 seconds, or with multiple Faraday cups in static analysis mode for samples with greater than approximately $200 \mathrm{pg}$ (picograms) total Os. Rhenium is collected with Faraday cups used in static mode as the negative ${ }^{249}\left(\mathrm{ReO}_{4}\right)^{-}$and ${ }^{251}\left(\mathrm{ReO}_{4}\right)^{-}$ions.

Corrections to the Os isotopic composition (software provide by Monash University) are made for mass fractionation bias introduced by the higher ionization efficiency of lighter isotopes of Os (or Re), the variable contributions of the three isotopes of oxygen, isobaric interference of ${ }^{187} \mathrm{Re}$, and spike composition.

The first round of mass fractionation correction is related to oxygen isotopes and adjusts the 240/236 mass ratio, nominally the ${ }^{192} \mathrm{Os} /{ }^{188} \mathrm{Os}$ ratio of the negative trioxide ion, using the ${ }^{192} \mathrm{Os} /{ }^{188} \mathrm{Os}$ value of 3.09219 (Hauri and Hart, 1993) and the revised values for the isotopic composition of oxygen (Nier's, 1950).

Any Re present must be corrected for because the trioxide of ${ }^{187} \mathrm{Re}$ (mass of 235) creates isobaric interference of the trioxide ${ }^{187}$ Os (mass of 235). However, no isobaric interference of Os results from the trioxide of ${ }^{185} \mathrm{Re}$ (mass 233) and therefore the measured 233 mass is used to correct the measured ${ }^{187} \mathrm{Os}$ value.

The Os data are further corrected for the contribution of the Os spike to the isotopic composition of the sample, as the spike contains measurable amounts of isotopes other than ${ }^{190} \mathrm{Os}$, in particular the isotope of interest, ${ }^{187} \mathrm{Os}$. A second round mass fractionation correction is then performed using the value of ${ }^{192} \mathrm{Os} /{ }^{188} \mathrm{Os}=3.08271$ (Luck and Allègre, 1983; Reisberg et al., 1991; Horan et al., 1992).

A similar procedure would be adopted for mass fractionation and oxygen correction of the Re data, however, in this case there is no internal mass fractionation correction possible as there are only two isotopes of Re. Multiple analyses of the Re isotopic standard indicate that the mass fractionation involved is negligible at the low temperatures at which Re ionizes, and furthermore is within the error of the isotope dilution method used to calculate the abundance of Re. 


\section{Precision, accuracy, and blanks}

The best way to assess the precision and accuracy of any analytical technique is to compare data obtained on certified reference materials with the certified values and published data. However, at present there are no certified reference materials for the Re-Os isotopic system, which results in large part from the aforementioned "nugget effect". This makes the selection and preparation of a suitable reference material difficult. However, for the purposes of general comparison, the Wellgreen altered-peridotite precious metals standard WPR-1 has been used by several groups (Cohen and Waters, 1996; Lahaye et al., 2001) and is used here primarily for the purpose of inter-laboratory comparison. The WPR-1 standard has a relatively moderate $\mathrm{Re}$ and Os concentration of approximately 11-12 and 15-18 ppb respectively and is the same order of magnitude as some unknown samples routinely analyzed. Re-Os results determined at CPGeo (Table 2) are precise with the exception of one analysis. If this outlier is eliminated from the data set the precision is enhanced greatly (e.g. the relative standard error on ${ }^{187} \mathrm{Os} /{ }^{188} \mathrm{Os}$ decreases from 0.001 to 0.0003 ), as 4 of the 5 analyses form a tight cluster of values. The CPGeo determinations for the Os concentrations of WPR-1 are slightly higher and the ${ }^{187} \mathrm{Os} /{ }^{188} \mathrm{Os}$ ratios slightly lower than those determined by other laboratories. These differences likely are caused by variations within the standard powder between laboratories or as a result of inhomogeneities within the standard powder itself. This "nugget effect” could also be responsible for the anomalous result of the outlier. However as shown by analyses of the mass spectrometry standard (below) the difficulties in analysing the WPR standard is not as a result of systematic measurement errors.

Bias introduced during mass spectrometry as well as interlaboratory variation is assessed by the analysis of a mass spectrometry standard provided by the Department of Terrestrial Magnetism (DTM). This standard was made using Johnson-Mathey ammonium hexachlorosmate from the batch 5.56870-A, and shows little variation between analyses. At CPGeo, this isotopic standard is run with every batch of mass spectrometric analyses. Comparison of DTM, Monash and CPGeo N-TIMS data are shown in Table 3.

\section{Analytical blanks}

Analytical blanks have a significant effect on the usefulness of isotopic analyses. Blank measurements made at CPGeo were extremely low at approximately $1 \mathrm{pg}$ for Os with a ${ }^{187} \mathrm{Os} /{ }^{188} \mathrm{Os}$ value of $\sim 0.17$ and $5-10 \mathrm{pg}$ for Re. At these levels the blank correction of measured samples is negligible for most rock types.

Table 2. Os data for WPR-1 precious metals standard. Data for OU (Open University) from Cohen and Waters (1996). ${ }^{*}=$ Errors are external precision (2RSD). ${ }^{* *}=$ Distillation, all others solvent extraction.

\begin{tabular}{cccc}
\hline Laboratory & Os $(\mathrm{ppb})$ & $\operatorname{Re}(\mathrm{ppb})$ & ${ }^{187} \mathrm{Os} /{ }^{188}$ Os \\
\hline OU & $15.82 \pm 1.14$ & - & $0.14549 \pm 0.00018^{*}$ \\
& $(n=6)$ & & $(\mathrm{n}=6)$ \\
OU & $16.06 \pm 0.80$ & - & $0.14543 \pm 0.00018^{*}$ \\
& $(n=3)$ & & $(\mathrm{n}=3)$ \\
Monash & $16.79 \pm 0.27$ & $11.62 \pm 0.13$ & $0.14507 \pm 0.00283^{*}$ \\
& $(n=9)$ & $(n=3)$ & $(n=9)$ \\
CPGeo & $17.55 \pm 1.19$ & $11.01 \pm 0.54$ & $0.14380 \pm 0.00129^{*}$ \\
& $(n=5)$ & $(n=5)$ & $(n=5)$ \\
\hline
\end{tabular}

Table 3. Comparison of DTM, Monash and CPGeo N-TIMS data for batch 5.56870-A. DTM data are from Shirey (1997). DTM data were all acquired in rapid peak hopping mode with a single detector.

\begin{tabular}{ccc}
\hline Laboratory & Detector & ${ }^{187}$ Os $/{ }^{188}$ Os \\
\hline Monash & SEM $(n=26)$ & $0.17396 \pm 58$ \\
Monash & Faraday $(n=10)$ & $0.17360 \pm 48$ \\
DTM & Pulse $(n=22)$ & $0.17429 \pm 55$ \\
DTM & Analog $(n=13)$ & $0.17396 \pm 38$ \\
CPGeo & SEM $(n=8)$ & $0.17379 \pm 65$ \\
CPGeo & Faraday $(n=8)$ & $0.17372 \pm 20$ \\
\hline
\end{tabular}




\section{CONCLUSIONS}

The Re-Os isotopic system is ideally suited to the study of mantle related processes and materials as well as ore deposition. In these contexts it may be used as both a geochronological tool, and as a tracer of geochemical processes. The newly established facility at CPGeo has the capability to measure values of the absolute concentrations of $\mathrm{Re}$ and Os and isotopic ratios of Os which have comparable precision and accuracy to other similar established laboratories, and will provide a valuable contribution to research on the timing, origin and history of ore deposition and together with other isotope methods a way to improve knowledge of regional geology, petrology and tectonic evolution in South America.

\section{ACKNOWLEDGEMENTS}

The authors give thanks for the support provided by the Programa de Apoio a Núcleos de Excelência (PRONEX) through contract $n^{\circ}$ 41.96.0899.00 and the Fundação de Amparo à Pesquisa do Estado de São Paulo (FAPESP) through the Thematic Project $n^{\circ} 97 / 00640-5$. Louise Frick was supported by a FAPESP grant $n^{\circ} 98 / 13426-4$ and Jason Kirk through a post-doctorate FAPESP grant, $n^{\circ}$ 05/50391-0. Thanks are given to all the staff at CPGeo for assistance during the course of this work, to Sandra Andrade of the Laboratório de Química e ICP-AES/MS of the Departamento de Mineralogia e Geotectônica (GMG) of the Instituto de Geociências (IGc), and to the two anonymous reviewers that contributed to the improvement of the original manuscript.

\section{REFERENCES}

ALLÈGRE, C. J.; LUCK, J. M. Osmium isotopes as petrogenetic tracers. Earth and Planetary Science Letters, v. 48, p. 148-154, 1980.

BARRA, F.; RUIZ, J.; VALENCIA, V.A.; OCHOA-LANDÍN, L.; CHESLEY, J. T.; ZURHCER, L. Laramide porphyry CuMo mineralization in Northern Mexico: age constraints from Re-Os geochronology in molybdenite. Economic Geology, v. 100, p. 1605-1616, 2005.

BIRCK, J. L.; ROY BARMAN, M.; CAPMAS, F. Re-Os isotopic measurements at the femtomole level in natural samples. Geostandards Newsletter, v. 20, p. 19-27, 1997.

BRANDON, A. D.; CREASER, R. A.; SHIREY, S. B.; CARLSON, R. W. Osmium recycling in subduction zones. Science, v. 272, p. 861-864, 1996.
BRANDON, A. D.; SNOW, J. E.; WALKER, R. J.; MORGAN, J. W.; MOCK, T. D. ${ }^{190} \mathrm{Pt}-{ }^{186}$ Os and ${ }^{187} \mathrm{Re}-{ }^{187}$ Os systematics of abyssal peridotites. Earth and Planetary Science Letter, v. 177, p. 319-335, 2000.

BRANDON, A. D.; WALKER, R. J.; MORGAN, J. W.; GOLES, G. G. Re-Os isotopic evidence for early differentiation of the Martian mantle. Geochimica et Cosmochimica Acta, v. 64, p. 4083-4095, 2000b.

CARLSON, R. W. Application of the Pt-Re-Os isotopic systems to mantle geochemistry and geochronology. Lihos, v. 82, p. 249-272, 2005.

CHEN, J. H.; PAPANASTASSIOU, D. A.; WASSERBURG G. J. Re-Os systematics in chondrites and the fractionation of the platinum group elements in the early solar system. Geochimica et Cosmochimica Acta, v. 62, p. 3379-3392, 1998.

CHESLEY, J.; RIGHTER, K.; RUIZ, J. Large-scale mantle metasomatism: a Re-Os perspective. Earth and Planetary Science Letters, v. 219, p. 49-60.

COHEN, A. S.; WATERS, F. G. Separation of osmium from geological materials by solvent extraction for analysis by thermal ionisation mass spectrometry. Analytica Chimica Acta, v. 332, p. 269-275, 1996.

CROCKET, J. H.; FLEET, M. E.; STONE, W. E. Experimental partitioning of osmium, iridium and gold between basalt melt and sulphide liquid at $1300^{\circ} \mathrm{C}$. Australian Journal of Earth Sciences, v. 39, p. 427-432, 1992.

FOSTER, J. G.; LAMBERT, D. D.; FRICK, L. R.; MAAS, R. Re-Os isotopic evidence for genesis of Archaean nickel ores from uncontaminated komatiites. Nature, v. 382, p. 703-706, 1996.

GIRARDI, V.A.V.; FERRARIO,A.; CORREIA, C. T.; DIELLA, V. A comparison of selected Precambrian Brazilian chromitites: Chromite, PGE-PGM, and Re/Os as parental source indicators. Journal of South American Earth Sciences, v. 20, p. 303-313, 2006.

HAURI, E. K.; HART, S. R. Re-Os isotope systematics of HIMU and EMII oceanic island basalts from the south Pacific Ocean. Earth and Planetary Science Letters, v. 114, p. 353-371, 1993.

HAURI, E. K.; HART, S. R. Rhenium abundances and systematics in oceanic basalts. Chemical Geology, v. 139, p. 185-205, 1997. 
HOLZHEID, A.; SYLVESTER, P.; O’NEIL, H. St. C.; RUBIE, D. C.; PALME, H. Evidence for a late chondritic veneer in the Earth's mantle from high-pressure partitioning of palladium and platinum. Nature, v. 406, p. 396-399, 2000.

HORAN, M. F.; MORGAN, J. W.; WALKER, R. J.; GROSSMAN, J. N. Rhenium-osmium isotope constraints on the age of iron meteorites. Science, v. 255, p. 1118-1121, 1992.

JONES, J. H.; DRAKE, M. J. Geochemical constraints on core formation in the Earth. Nature, v. 322, p. 221-228, 1986.

KENDALL, B.; CREASER, R. A.; SELBY, D. Re-Os geochronology of postglacial black shales in Australia: Constraints on the timing of "Sturtian" glaciation. Geology, v. 34, p. 729-732, 2006.

KIRK, J.; RUIZ, J.; CHESLEY, J.; TITLEY, S.; WALSHE, J.A detrital model for the origin of gold and sulfides in the Witswaterrand basin based on Re-Os isotopes. Geochimica et Cosmochimica Acta. v. 65, p. 2149-2159, 2001.

KIRK, J.; RUIZ, J.; CHESLEY, J.; WALSHE, J.; ENGLAND, G. A major Archean, gold- and crust-forming event in the Kaapvaal Craton, South Africa. Science, v. 297, p. 1856-1858, 2002.

LAHAYE, Y.; BARNES, S.J.; FRICK, L.R.; LAMBERT, D.D. Re-Os isotopic study of komatiitic volcanism and magmatic sulfide formation in the Southern Abitibi Greenstone Belt, Ontario, Canada. The Canadian Minerologist, v. 39, p. 473-490, 2001.

LAMBERT, D. D.; FOSTER, J. G.; FRICK, L. R.; RIPLEY, E. M.; ZIENTEK, M. L. Geodynamics of magmatic Cu-Ni-PGE sulfide deposits: New insights from the Re-Os isotope system. Economic Geology, v. 93, p. 121-136, 1998.

LUCK, J. M.; ALLÈGRE, C. J. The study of molybdenites through the ${ }^{187} \mathrm{Re}^{187}$ Os chronometer. Earth and Planetary Science Letters, v. 61, p. 291-296, 1982.

LUCK, J. M.; ALLÈGRE, C. J. ${ }^{187}$ Re- ${ }^{187}$ Os systematics in meteorites and cosmochemical consequences. Nature, v. 302, p. 130-132, 1983.

LUCK, J. M.; ALLÈGRE, C. J. Osmium isotopes in ophiolites. Earth and Planetary Science Letters, v. 107, p. 406-415, 1991.

MATHUR, R.; MARSCHIK, R.; RUIZ, J.; MUNIZAGA, F.; LEVEILLE, R. A.; MARTIN, W. Age of mineralization of the Candelaria Fe oxide $\mathrm{Cu}-\mathrm{Au}$ deposit and the origin of the
Chilean iron belt, based on Re-Os isotopes. Economic Geology and the Bulletin of the Society of Economic Geologists, v. 97, p. 59-71, 2002.

McCANDLESS, T. E.; RUIZ, J.; CAMPBELL, A. R. Rhenium behaviour in molybdenite in hypogene and near-surface environments: implications for Re-Os geochronometry. Geochimica et Cosmochimica Acta, v. 57, p. 889-905, 1993.

McINNES, B. I.A.; EVANS, N. J.; McBRIDE, J. S.; LAMBERT, D. D. Osmium isotope and noble metal enrichement of the mantle source region of the Ladolam gold deposit, Lihir Island, PNG. Geological Society of America. Abstracts with programs, A302, 1998.

MEISEL, T.; GIUSEPPE, G. B.; NÄGLER, T. F. Re-Os, Sm-Nd, and rare earth element evidence for Proterozoic oceanic and possible subcontinental lithosphere in tectonized ultramafic lenses from the Swiss Alps. Geochimica et Cosmochimica Acta, v. 60, p. 2583-2593, 1996.

MEISEL, T.; WALKER, R. J.; IRVING, A. J.; LORAND, J. P. Osmium isotopic compositions of mantle xenoliths: a global perspective. Geochimica et Cosmochimica Acta, v. 65, p. 1311-1323, 2001.

MORGAN, J. W.; WALKER, R. J. Isotopic determinations of rhenium and osmium in meteorites by using fusion, distillation and ion-exchange separations. Analytica Chimica Acta, v. 222, p. 291-300, 1989.

NIER, A. O. A redetermination of the relative abundances of the isotopes of carbon, nitrogen, oxygen, argon and potassium. Physics Reviews, v. 77, p. 789-793, 1950.

PEARSON, D. G.; CARLSON, R. W.; SHIREY, S. B.; BOYD, F. R.; NIXON, P. H. Stabilisation of Archaean lithospheric mantle: A Re-Os isotope study of peridotite xenoliths from the Kaapvaal craton. Earth and Planetary Science Letters, v. 134, p. 341-357, 1995a.

PEARSON, D. G.; SHIREY, S. B.; CARLSON, R. W.; BOYD, F. R.; POKHILENKO, N. P.; SHIMIZU, N. Re-Os, Sm-Nd, and $\mathrm{Rb}-\mathrm{Sr}$ isotope evidence for thick Archaean lithospheric mantle beneath the Siberian craton modified by multi-stage metasomatism. Geochimica et Cosmochimica Acta, v. 59, p. 959-977, 1995b.

PEARSON, D. G. The age of continental roots. Lithos, v. 48, p. 171-194, 1999.

POTTS, P. J. Sample strategies: inhomogeneity effects. In: 
POTTS, P. J. A handbook of silicate rock analysis. London; Weinheim: Blackie Academic \& Professional, 1987, p. 18-20.

REISBERG, L. C.; ALLÈGRE, C. J.; LUCK, J. M. The Re-Os systematics of the Rhonda Ultramafic Complex of southern Spain. Earth and Planetary Science Letters, v. 105, p. 196-213, 1991.

RIGHTER, K.; CHESLEY, J. T.; GEIST, D.; RUIZ, J. Behavior of Re during magma fractionation: an example from Volcán Alcedo, Galápagos. Journal of Petrology, v. 39, p. 785-795, 1998.

ROY-BARMAN, M.; WASSERBURG, G. J.; PAPANASTASSIOU, D.A.; CHAUSSIDON, M. Osmium isotope compositions and $\mathrm{Re}-\mathrm{Os}$ concentrations in sulfide globules from basaltic glasses. Earth and Planetary Science Letters, v. 154, p. 331-347, 1998.

SELBY, D.; CREASER, R. A. Direct radiometric dating of the Devonian-Mississippian time-scale boundary using the Re-Os black shale geochronometer. Geology, v. 33, p. 545-548, 2005.

SELBY, D.; CREASER, R. A.; HART, C. J. R.; ROMBACH, C. S. Absolute timing of sulfide and gold mineralization: A comparison of Re-Os molybdenite and Ar-Ar mica methods from the Tintina Gold Belt, Alaska. Geology, v. 30, p. 791-794, 2002.

SHEN, J. J.; PAPANASTASSIOU, D. A.; WASSERBURG, G. J. Precise Re-Os determinations and systematics of iron meteorites. Geochimica et Cosmochimica Acta, v. 60, p. 2887-2900, 1996.

SHIREY, S. B.; WALKER, R. J. Re-Os isotopes in cosmochemistry and high-temperature geochemistry. Annual Reviews of Earth and Planetary Sciences, v. 26, p. 423-500, 1998.

SHIREY, S. B.; WALKER, R. J.; BOYD, F. R. Os, Sr, Nd, and $\mathrm{Pb}$ isotope systematics of southern African peridotite xenoliths: Implications for the chemical evolution of subcontinental mantle. Geochimica et Cosmochimica Acta, v. 53, p. 1583-1595, 1989.

SHIREY, S. B. Re-Os isotopic compositions of Midcontinent rift system picrites: implications for plume-lithosphere interaction and enriched mantle sources. Canadian Journal of Earth Sciences, v. 34, p. 489-503, 1997.

SHIREY, S. B.; WALKER, R. J. Carius tube digestions for
Re-Os Chemistry: An old technique applied to new problems. Eos, Transactions American Geophysical Union, v. 75, n. 16, p. 355, 1994.

SHIREY, S. B.; WALKER, R. J. Carius tube digestion for low-blank rhenium-osmium analysis. Analytical Chemistry, v. 67, n. 13, p. 2136-2141, 1995.

SMOLIAR, M. I.; WALKER, R. J.; MORGAN, J. W. Re-Os ages of group IIa, IIIA, IVA, and IVB iron meteorites. Science, v. 271, p. 1099-1102, 1996.

SNOW, J. E.; REISBERG, L. Os isotopic systematics of the MORB mantle: results from altered abyssal peridotites. Earth and Planetary Science Letters, v. 133, p. 411-421, 1995.

WALKER, R. J.; FASSETT, J. D. Isotopic measurement of subnanogram quantities of rhenium and osmium by resonance ionization mass spectrometry. Analytical Chemistry, v. 58, p. 2923-2927, 1986.

WALKER, R. J.; MORGAN, J. W. Rhenium-osmium isotope systematics of carbonaceous chondrites. Science, v. 243, p. 519-522, 1989.

WALKER, R. J.; CARLSON, R.W.; SHIREY, S. B.; BOYD, F. R. Os, $\mathrm{Sr}, \mathrm{Nd}$, and $\mathrm{Pb}$ isotope systematics of southern African peridotite xenoliths: implications for the chemical evolution of subcontinental mantle. Geochimica et Cosmochimica Acta, v. 53, p. 1583-1595, $1989 \mathrm{~b}$.

WALKER, R. J.; PRICHARD, H. M.; ISHIWATARI, A.; PIMENTEL, M. The osmium isotopic composition of convecting upper mantle deduced from ophiolite chromites. Geochimica et Cosmochimica Acta, v. 66, p. 329-345, 2002.

WALKER, R. J.; HORAN, M. F.; SHEARER, C. K.; PAPIKE, J. J. Depletion of highly siderophile elements in the lunar mantle: evidence for prolonged late accretion. Earth and Planetary Science Letters, v. 224, p. 399-413, 2004.

YIN, Q. Z.; JACOBSEN, S. B.; LEE, C. T.; McDONOUGH, W. F.; RUDNICK, R. L.; HORN, I. A gravimetric $\mathrm{K}_{2} \mathrm{OsCl}_{6}$ standard: Application to precise and accurate Os spike calibration. Geochimica et Cosmochimica Acta, v. 65, p. 2113-2127, 2001. 